\title{
ACCESSIBILITY OF REAL ESTATE BY TRANSPORTATION AS A DETERMINANT OF THE DEVELOPMENT OF SUBURBAN REAL ESTATE MARKETS - CASE STUDY
}

\author{
Ada Wolny, PhD \\ Faculty of Geodesy, Geospatial and Civil Engineering \\ University of Warmia and Mazury in Olsztyn \\ e-mail:ada.wolny@uwm.edu.pl
}

\begin{abstract}
The aim of this article is to show the accessibility of real estate by transportation as a factor that significantly determines the decision to acquire it. Direct access to a public road, or access to an internal road that provides communication with the public road, are a factor affecting the value of real estate. In addition, this factor is taken into account in the process of changing the function of the area, especially in determining zoning and land use. The decision of purchasing real estate often depends on transportation accessibility, because it has an impact on developing the selected plot.

Suburban real estate markets, as markets exposed to particularly strong investment pressure, develop depending on the influx of external investors and the local transportation network. Here, the smaller the distance from the city center, the greater the building concentration; nevertheless, it is still important to improve transportation links and create a well-developed local transportation network. The provision of access to main roads on the rapidly growing market is in the interest of local authorities implementing spatial policy. It is also a challenge for real estate investors taking on the initiative in the scope of transforming land use.

The analysis of the impact that transportation accessibility has on the development of the real estate market was conducted on the example of two selected suburban communes bordering the city of Olsztyn - Dywity and Stawiguda. Transactions on the local real estate market entered into during a period of five years were subjected to analysis. The results of the research revealed concentrations of transactions of real estate located on the outskirts of the city or in areas well-communicated with Olsztyn. The conducted research also indicates that, due to the activity of investors, a network of internal roads creating a complex structure was formed.
\end{abstract}

Key words: suburbanization, transportation, concentration, real estate market.

JEL Classification: C26, R39, R42.

Citation: Wolny A., 2016, Accessibility of Real Estate by Transportation as a Determinant of the Development of Suburban Real Estate Markets - Case Study, Real Estate Management and Valuation, Vol. 24, No. 1, pp. 5-18.

DOI: $10.1515 /$ remav-2016-0001

\section{Introduction}

Suburbs are exposed to particularly strong investment pressure resulting from the expansion of the city into areas neighboring the city borders. Progressing settlement and the influx of urban residents to the suburbs are usually connected with the local community's demand for the development of existing transportation systems. The most common type of dispersed development in the suburbs arises with the formation of housing along the main roads. 
This type of housing development is a direct result of urbanization processes, in particular suburbanization. The concept of suburbanization etymologically derives from "suburbium", which means a peripheral in relation to the developed areas in the city, or adjacent to the administrative borders of the city (situated near) housing area (rather the zone of "urban fringe" than "rural-urban fringe") (LISOWSKI, GROCHOWSKI 2008).

The concept of suburbanization has been identified with one of the phases of the development of a city, characterized by the depopulation of the center and the development of suburban areas. The main results of suburbanization include the development of technical and social infrastructure, housing, retail and service buildings, and transportation, as well as the creation of settlements outside the city.

According to HOPFER and others (2006), spatial diffusion processes take place on the outskirts of the city - these are processes of progressive succession from the city center towards the peripheral zones. This phenomenon appears as replacing less intensive forms of land use by more intensive ones. The intensity of the land use forms decreases with increasing distance from the city center.

Factors affecting suburbanization processes include (LORENS 2005):

- the ability to satisfy the needs of housing freely, with the dominant preference for a "house with a garden",

- the lack of coordination in the spatial policy of cities and metropolitan areas;

- the pursuit of developers and investors in developing easily accessible areas (quality and price).

Suburbanization may take a dispersed form defined as urban sprawl. The main features of this process, according to which an area of urban sprawl may be identified in space (GALSTER and other 2001), are:

- a significant distance between different forms of land use,

- low development density,

- a lack of continuity and uniformity of land use,

- unilateral land use,

- local concentration of land use,

- low centrality of spatial organization.

A diagram illustrating how urban sprawl takes place has been presented in Fig. 1.

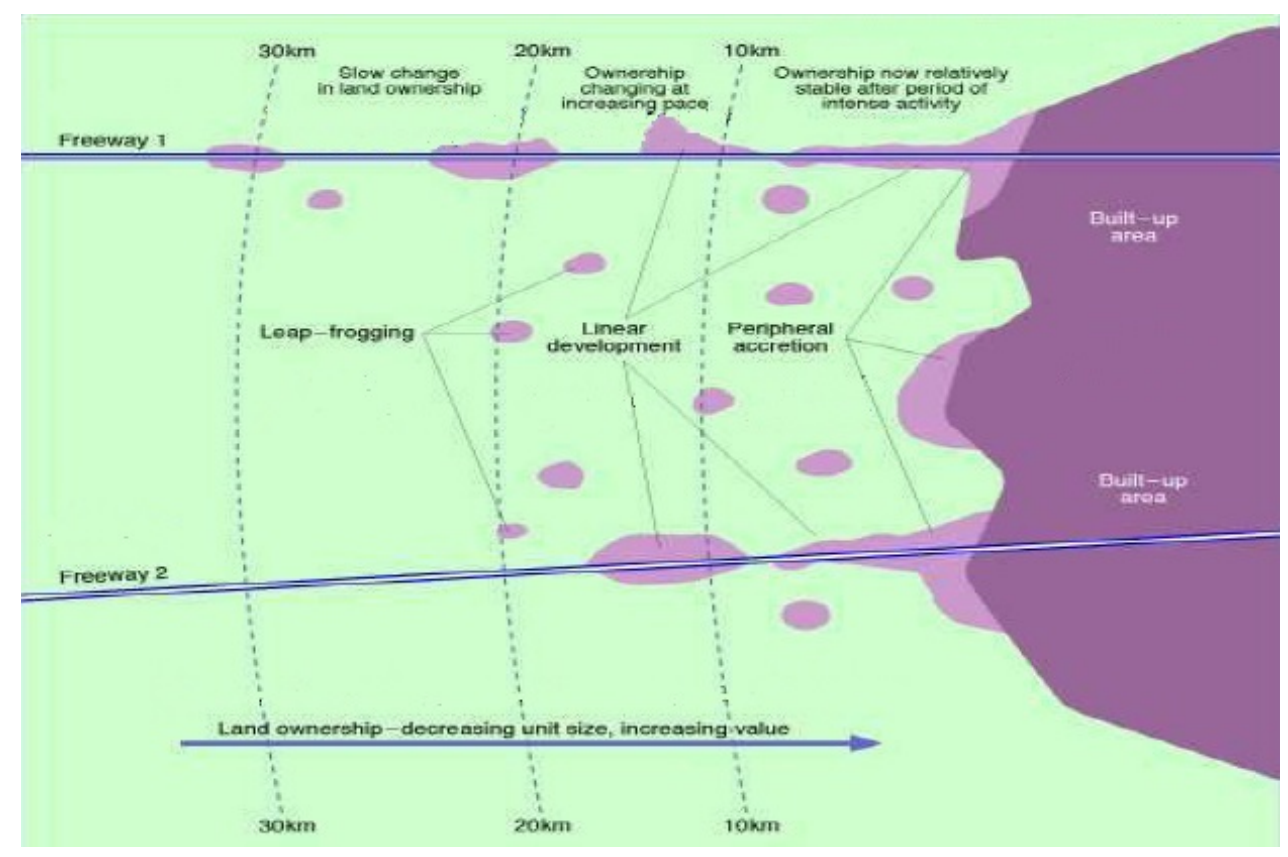

Fig. 1. Urban sprawl. Source: Own study based on LISOWSKI, GROCHOWSKI, 2008 cited in www.geocases.co.uk.

Despite the high investment potential of city centers, investing outside the cities is easier and less expensive, so we may observe the progressive sprawl of suburbs and dispersed housing in rural areas 
(KRONENBERG, BERGIER 2010). New settlements are concentrated in regions which are easily accessible - along freeways and main routes leading to the city. Initially, development takes the form of peripheral accretion, which subsequently becomes linear. Finally, along with increasing distance from the city, only leap - frogging development tends to appear commonly (Fig. 1). Next, new roads are created in the emerging built-up areas, mostly in the form of internal roads. Transport accessibility, as a determinant of real estate development in suburban areas, also affects the supply of real estate in local markets. Direct access to the public road or access to an internal road that provides communication with the public road are both factors affecting the value of real estate. In addition, access to a road is taken into consideration in the process of changing land use, and above all, when determining the conditions for land development. The decision of whether to purchase real estate often depends on accessibility to transportation routes, as it has an impact on the possibility of building up the given plot.

According to a theory put forth by GEURS and VAN WEE (2006), land use allocation depends on four elements: cellular accessibility, based on zonal accessibility levels by car and public transport for different activities, and local distances to roads and rail infrastructure, railway stations, motorway approaches and exits; physical suitability as described in national and regional land use policy plans; and the neighborhood effect, which is the combined effect of attraction and repulsion by the function of the distance separating the different functions within the neighborhood.

As confirmed by an analysis of literature, accessibility has a significant impact on the development of areas and changes in the structure of land use, which is reflected in the increased attractiveness of suburban markets, where the majority of target customers are people connected with the city on a daily basis.

\section{Characteristic of suburban real estate markets}

\subsection{The concept of a real estate market}

The concept of a market has many meanings. When referring to a market in this work, we mean the entirety of purchase and sale transactions, as well as the conditions under which they take place (MILEWSKI, KWIATKOWSKI 2004).

The real estate market may be, according to M. TROJANEK (2009), placed in both the real and financial markets. The residential real estate can undoubtedly be classified as durable consumer goods. These goods are characterized by a high price of purchase and a very long period of "consumption". On the other hand, the real estate market can be classified as an investment goods market. The main sources of benefits for the investor are incomes (rent and other) generated by the real estate.

The market is also a process through which the interactions between the purchasers and sellers of a particular good lead to determining its prices and quantities (SAMUELSON, NORDHAUS 1995). Moreover, the real estate market is described as the entirety of relations occurring between the sellers, who are responsible for market offers - sales of real estate, and investors declaring the demand for certain real estate, supported by a readiness to pay. The real estate market, according to this definition, includes (KUCHARSKA-STASIAK 2004):

- market subjects, which comprise the sellers and purchasers, and some ownership rights to the real estate or individual property assets constituting the real estate,

- market objects, which are the real estate or their asset components,

- market relations, which are the mutual relations between market entities.

According to a detailed definition, the subjects active on the real estate market are natural and legal persons, both public and private, who have various rights to real estate (for example: leasing, renting, ownership), as well as subjects operating on the real estate market, such as real estate appraisers, managers, brokers, developers, etc. The objects comprise three types of real estate (land, buildings and housing or business units) and the rights connected with them (GROSS and ŹRÓBEK 2015).

According to the mechanisms of changes in demand and supply, many researchers state that the real estate market is subjected to cycles (BARRAS 1994, GRANELLE 1998, HERRING, WATCHER 1999, ROTTKE AND WERNECKE 2002). The traditional cycle of real estate market development depends on the economic development of the country. Researchers believe this simple relationship to still exist, though without absolute synchronicity between the two (GRANELLE 1998). BARRAS (1994) points to four phases of the cycle: economic recovery, economic boom, economic turnaround, and recession, 
which are accompanied by reactions of the market. Real estate market cycles are recurrent, though irregular fluctuations around the equilibrium level, which are also reflected in many other indicators concerning real estate (PEISER, FRAJ 2007). The cycles had an impact on the assumptions of real estate market analysis in this article.

\subsection{Specificity of suburban real estate markets}

The specific character of suburban real estate markets depends on the needs of purchasers. Most of them aim to satisfy their housing needs; that is why the outskirts of the city, as well as entire suburban area, are perceived through the prism of an extended housing market.

The housing market is encountered, first and foremost (if not exclusively), as a separate, selfcontained economic entity - an economic object (SMITH S. and others 2006). The population migrating to the suburbs is interested in:

- undeveloped land with the possibility of residential development in the form of single-family detached, semi-detached or terraced housing,

- built-up real estate with single-family housing,

- dwellings in blocks of flats developing on the rural-urban border.

The suburban real estate market has features distinguishing it from typical rural markets. Along with the transformation of areas, the value of individual real estate increases, and the price of the plot depends, to a large extent, on its localization - distance from the city center and transport accessibility. The further away the real estate is located, the less attractive and less valuable for investors it becomes, with the exception of properties intended for special purposes (WOLNY, ŹRÓBEK 2008).

Previous studies (KRAJEWSKA 2010 and FORYŚ, PUTEK-SZELĄG 2008) demonstrate that circumstances that are taken into consideration by investors (future purchasers) can be used for distinguishing segments of land in the suburban real estate market, such as:

1) agricultural land acquired for the purpose of conducting activities connected with agriculture,

2) agricultural land acquired as potential building property, so called "investment fields",

3) agricultural land acquired as potential building land, with a surface area between $3000-5000 \mathrm{~m}^{2}$,

4) land of high natural values acquired for recreational needs,

5) building plots (according to the definition in the Act on Spatial Planning and Development).

The specific character of land on the suburban real estate market was taken into consideration when creating the assumptions of the analysis of the selected research area. That is why the location and accessibility of the traded real estate were so important. On this basis, a research methodology was developed, and detailed research conducted.

\section{Methodology and characteristics of the research area}

\subsection{Methodology}

Suburban real estate markets, as markets exposed to particularly strong investment pressure, develop depending upon the influx of external investors who acquire land for development - mainly housing. It is essential to ensure transport accessibility to the real estate by means of a local transportation network. Such accessibility determines the development of suburban markets. Therefore, the aim of this article is to present the transport accessibility of real estate as a significant factor affecting the decision behind its purchase.

Due to the aim of this elaboration, the first stage of research was the analysis of literature pertaining to the topic of study. Next, the research area was selected, as well as determining a five-year period of analysis. Information from the real estate market was used for the analyses, which were carried out under the following conditions:

1) the analysis regarded sales transactions,

2) transactions involved undeveloped land,

3) the real estate was the property of the seller,

4) the analysis was carried out over a medium-term period, from 2007 to 2011,with the following determinants:

- data were derived from the electronic register of prices and values,

- the period of analysis covers the years of the so-called "investment boom", with its culmination in 2007-2008,

- the analysis also covers a period of decline in activity on the real estate market, followed by a period of significant recovery, 
5) the real estate may consist of one or several plots, but located within a single precinct,

6) the analysis especially accounts for unit prices and the type of use or function from the land use plan.

Information used for the needs of this elaboration was derived from: the register of real estate prices and values, CSO statistics, local registers, public information bulletins, documents provided by the communes, and local planning information systems.

Finally, cases where internal roads were purchased were distinguished, and a detailed analysis carried out with the use of a case study method.

The adopted research procedure has been presented in Fig. 2.

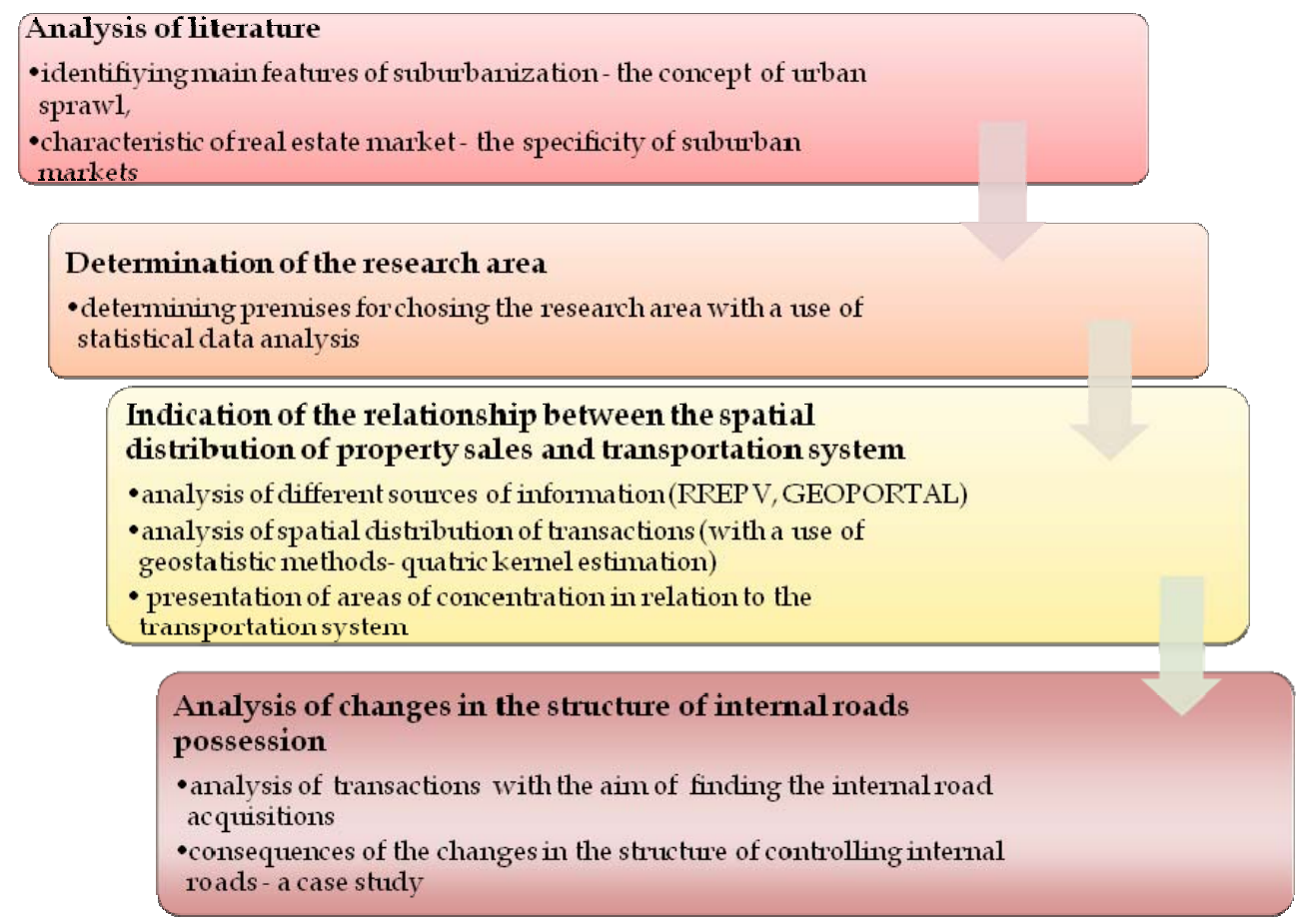

Fig. 2. Stages of research and methods. Source: own study.

\subsection{Characteristics of the research area}

For purposes of the present paper, analyses were conducted in the area of two suburban communes bordering Olsztyn, i.e. Dywity and Stawiguda. These communes lie on opposite sides of the city (one to the north, while the other to the south) and are not adjacent to one another.

Fig. 3 presents the location of the communes in relation to the urban center.

Selected statistical values characterizing demographic development

\begin{tabular}{lccc}
\hline \multicolumn{1}{c}{ Specification } & \multicolumn{2}{c}{ Period of analysis } & Dynamic \\
\cline { 2 - 4 } & $\mathbf{2 0 0 7}$ & $\mathbf{2 0 1 1}$ & \% growth \\
\hline & Stawiguda & & \\
\hline Population [people] & 5386 & 6775 & $\mathbf{2 5 \%}$ \\
\hline Population density [people $/ \mathrm{km}^{2}$ ] & 24 & 30 & - \\
\hline Balance of migration [people] & 230 & 349 & $11 \%$ \\
\hline Population [people] & Dywity & & $10 \%$ \\
\hline Population density [people $/ \mathrm{km}^{2}$ ] & 9620 & 10642 & - \\
\hline Balance of migration [people] & 60 & 66 & 191 \\
\hline
\end{tabular}

Source: Own study based on www.stat.gov.pl. 
Both communes are characterized by dynamic demographic development. The population growth is relatively high for rural areas (Table 1). A positive migration balance influences an increase in demand on the real estate market - the selected area is perceived as attractive for investments.

The research covered the years 2007-2011; thus, the characteristics of demographic development involved the extremes of this period (Table 1).

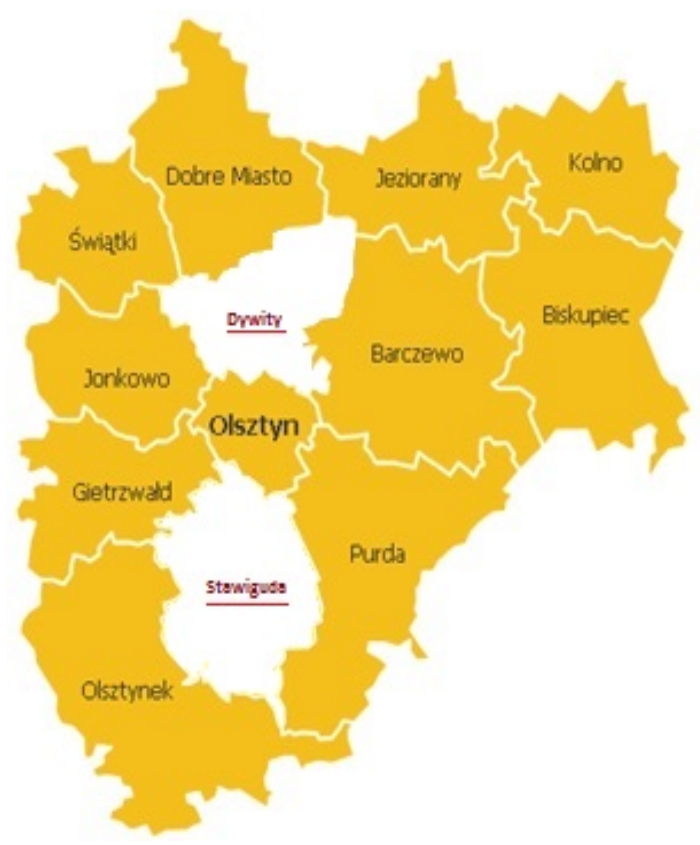

Fig. 3. Location of communes within the district. Source: WOLNY et al. (2014).

As statistical data from Table 1 show, the population and population density in the commune of Stawiguda have increased by $25 \%$ within 5 years. In the Dywity commune, this increase was analogically $10 \%$ and $11 \%$. Despite the lower population, growth in the commune of Stawiguda is higher than in the commune of Dywity. Balances of migration are positive in both communes, but in 2011, the balance for Dywity is lower than it had been in 2007, while in the commune of Stawiguda, the situation is opposite.

The constantly increasing population, population density and migration balance were important criteria for selecting the communes of Dywity and Stawiguda among the other communes neighboring Olsztyn. Moreover, it should be stressed that the areas within the administrative borders of both communes are subjected to intense transformation as a result of adopted land use plans, as well as decisions regarding building conditions. Table 2 presents the number of plans and decisions that were submitted for transformation between 2007 and 2011.

As shown by data in Table 2, both communes were areas of intense planning work in the period of 2007-2011, resulting in over a dozen adopted local land use plans. According to the public information bulletins for the communes of Dywity and Stawiguda and http://sip.stawiguda.pl, most of the transformed areas are designated for housing. Other designated uses of land are mainly transportation and greenery in the housing estates.

Table 2

Tools applied for changing land use between 2007 and 2011

\begin{tabular}{lcc}
\hline Tools used & Dywity & Stawiguda \\
\hline Number of land use plans & & \\
\hline Total & $\mathbf{1 9}$ & $\mathbf{1 5}$ \\
\hline 2007 & 3 & - \\
\hline 2008 & 5 & 5 \\
\hline 2009 & 5 & 3 \\
\hline 2010 & 4 & 5 \\
\hline 2011 & 2 & 2 \\
\hline
\end{tabular}




\begin{tabular}{lcc}
\hline Number of decisions on building conditions & & \\
\hline total & $\mathbf{1 0 3 6}$ & $\mathbf{3 8 2}$ \\
\hline 2007 & 232 & 97 \\
\hline 2008 & 282 & 49 \\
\hline 2009 & 213 & 73 \\
\hline 2010 & 169 & 92 \\
\hline 2011 & 140 & 71 \\
\hline
\end{tabular}

Source: own study based on: http://bip.warmia.mazury.pl and http://bip.stawiguda.pl, http://stat.gov.pl/bdl.

The increased interest in land for development in both communes is also reflected in the number of decisions on building conditions in the years 2007-2011. In the commune of Stawiguda, dozens of decisions were made per year, in the commune of Dywity - up to several times more. The scale of spatial transformation was also important for determining the research area.

In spite of the significant similarities, the analyzed communes differ in terms of natural conditions. More than $50 \%$ of the area of the Stawiguda commune is covered by forests. Moreover, there are three large lakes: Łańskie, Pluszne and Wulpińskie, which is attractive to tourism and recreation (http://stawiguda.pl). In the Dywity, on the other hand, forests cover $27 \%$ of the area of the commune, while more than $61 \%$ is agricultural land (http://gminadywity.pl/). The next difference refers their location in relation to the city. The commune of Stawiguda borders a dynamically developing housing district, while Dywity commune is next to the city forest in the north part of Olsztyn, which is a natural barrier for development.

To summarize, the choice of the two communes was not random. The characteristics of the communes based on statistical data indicate their attractiveness for settlement, and different development barriers present in the communes are arguments for including both of them in the research.

\section{The analysis of relations between the transportation system and the spatial distribution of transactions}

The present work puts forth the thesis that the attractiveness of real estate is determined by its location, which depends on its position in relation to the transportation system. The acquisition of real estate, in addition to its price, is determined by it being located in an area well-communicated with the city, which provides places of work, education, and public as well as commercial services.

According to data from the register of prices and real estate values during the period from 2007 to 2011, 907 transactions were made in the commune of Dywity, and 765 in the commune of Stawiguda. The study was limited to undeveloped plots of land.

At the beginning of the research, an analysis was carried out to determine if certain parts of the communes are more popular than others (the majority of transactions occurring there), and which of the traded plots are designated for development. Table 3 presents the results.

Table 3

Sales transactions on the real estate market made during the period 2007-2011

\begin{tabular}{|c|c|c|c|c|}
\hline \multirow{3}{*}{ Commune } & \multicolumn{4}{|c|}{ Share in the total number of transactions } \\
\hline & \multirow{2}{*}{$\begin{array}{l}\text { Transactions of } \\
\text { real estate } \\
\text { designated for } \\
\text { development }\end{array}$} & \multicolumn{3}{|c|}{$\begin{array}{l}\text { Real estate transactions in the most popular } \\
\text { locations }\end{array}$} \\
\hline & & Total & $\begin{array}{l}\text { Land designated } \\
\text { for development }\end{array}$ & Other \\
\hline Dywity & $15 \%$ & $53 \%$ & $12 \%$ & $41 \%$ \\
\hline Stawiguda & $57 \%$ & $72 \%$ & $49 \%$ & $23 \%$ \\
\hline
\end{tabular}

Source: own study. 
According to data from Table 3, almost $60 \%$ of the traded plots are designated for development in the commune of Stawiguda, and more than $70 \%$ are located in only a few precincts (Stawiguda - in the central part of the commune, as well as Tomaszkowo, Dorotowo and Bartag which are near the city borders). In the commune of Dywity, these percentages are lower, particularly for real estate designated for development (because decisions are used more often). Still, the majority of transactions are concentrated in the south-eastern part of the commune (Dywity, Kieźliny, Różnowo and Ługwałd).

In order to determine spatial relationships, data were collected on all of the zoned land plots which had been purchased between 2007 and 2011 in the communes of Dywity and Stawiguda, including their plot numbers.

The collected primary data were transformed by assigning universal numbers to the parcels, and then imported to the Saga GIS program, where this information was visualized against a cartographic background, which included the location and boundaries of land plots in the two communes. The program was run to perform quatric kernel estimation. Data were assigned to the centroids of the plots which had been traded in the period of analysis. The results of the estimation were transferred onto a map with the road network highlighted.

The conducted analysis made it possible to define the regions with concentrations of transactions. Density distributions were determined for the communes of Dywity (Fig. 4) and Stawiguda (Fig. 5).

The road network was applied to maps made against a cartographic background confined to the borders of the two communes, and the main communicational axis was marked. In both cases, this axis was National Road No. 51, leading to Dobre Miasto in the commune of Dywity, and to Olsztynek in the commune of Stawiguda; the road is one of the main transportation routes in the region.

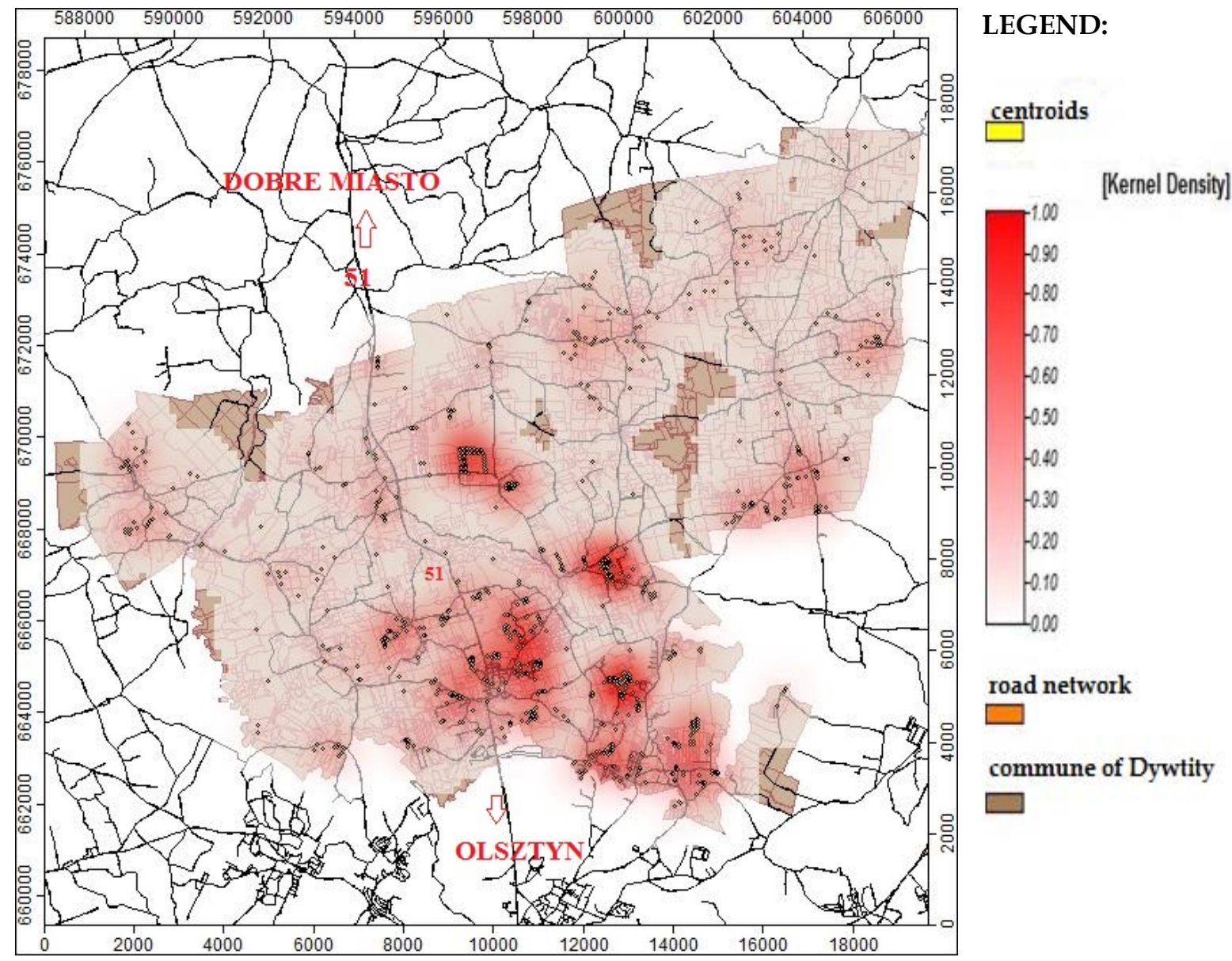

Fig. 4 Spatial distribution of transactions in the period 2007-2011 in Dywity Commune. Source: own study.

During the research, a concentration of transactions was observed on the urban-rural borderline. 
The majority of them were localized in the south part of the commune of Dywity and in the north part of the commune of Stawiguda. This demonstrates an increased interest of market participants in areas located closer to the city, under the growing investment pressure of Olsztyn's inhabitants. Moreover, it is evidence of the further expansion of the suburbs. As the distance from the city borders increases, transactions tend to be concentrated in areas which are well-communicated with the city, along the axis of National Road No. 51, as well as along roads of lower categories, in the proximity of the national roads (Fig. 4 and 5).

In both cases, there are areas where transactions practically do not occur, or are infrequent. These are the north-eastern and western parts of the commune of Dywity, and the south-eastern part of the commune of Stawiguda. Some single scattered transactions outside of the regions of concentration are also noted close to district and local (commune) roads (Fig. 4 and 5).

As a result of the conducted analyses, the spatial distribution of transactions with relation to the road network was obtained. The observed tendencies may subsequently lead to urban sprawl. The progressive linear development connected with the network of main roads and the tendency to result in "leap- frogging" may continue, particularly in Stawiguda Commune (Fig. 5).

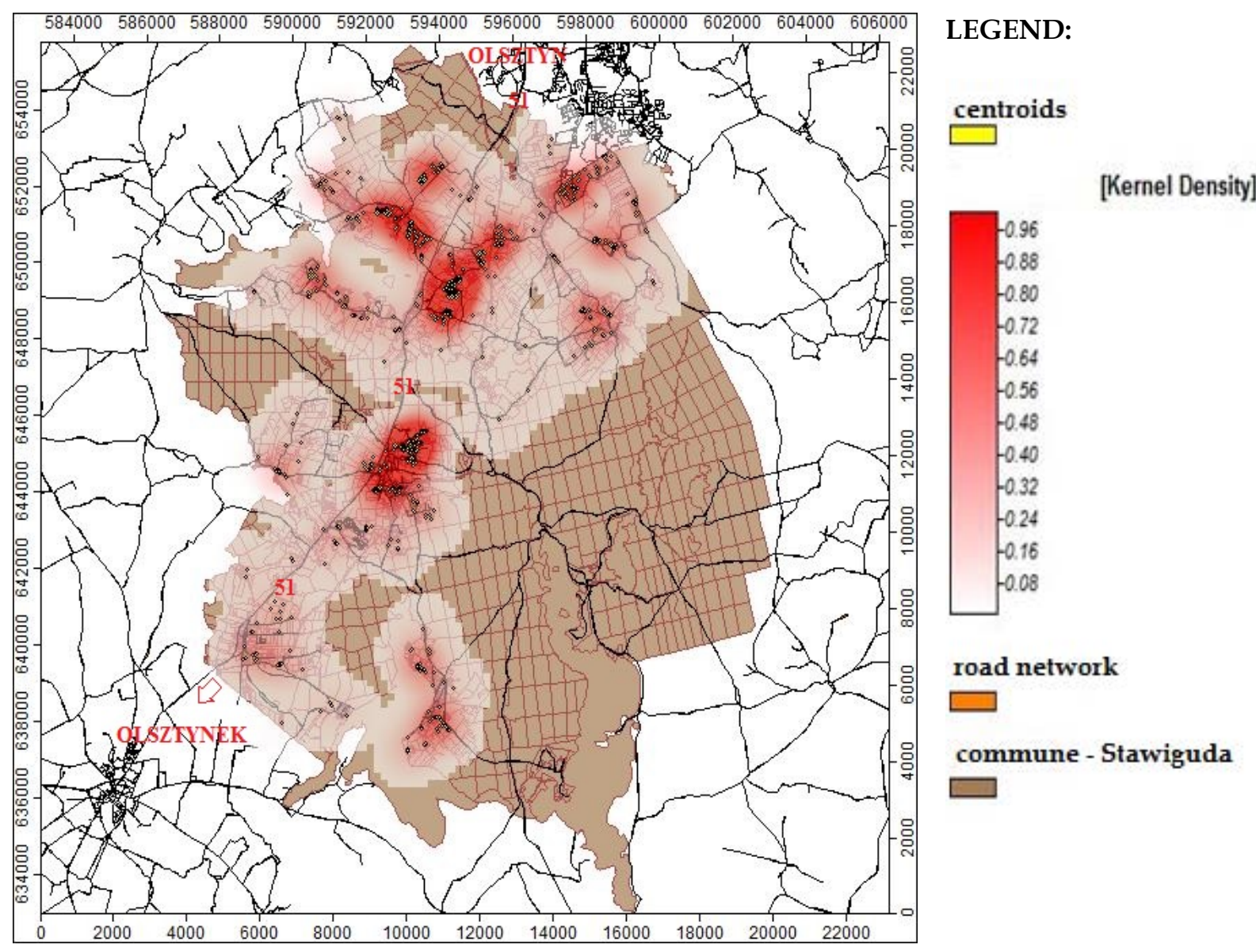

Fig. 5. Spatial distribution of transactions in the period 2007-2011 in Stawiguda. Source: own study.

\section{The analysis of acquisitions concerning internal roads}

During the analysis of the relationship between transportation accessibility and the attractiveness of real estate, some problematic areas were observed in the local real estate markets of the selected communes.

One of them is the acquisition of real estate designated for housing with a share in an internal road, which is often characterized by a complex structure. This share might be a part of the total price, it might be distinguished within the transaction with its price being "symbolic", or it might be acquired outside of the "main" transaction. The following diagram (Fig. 6) presents different options of "acquiring access" to the real estate.

The purchasers of adjacent plots with a common access road become members of a community of 
land. They have fractional shares in an internal road, which often consists of several plots. This access road should be kept in proper technical and functional condition; this means that any kind of activities carried out with the aim of keeping the road in a good state (such as repairs and clearing snow) are the responsibility of the co-owners. As the road is not public, the commune does not have to be concerned about its condition.

As it often happens, despite the undeniable advantages they offer to real estate located alongside them, access roads might be in a poor state, which greatly reduces the comfort of its users. Unfortunately, the suburban transportation system continues to be largely based on internal roads, and the above-described situation occurs relatively often. Therefore, a case study was carried out to characterize the transactions with shares in internal roads for selected areas of the two communes.
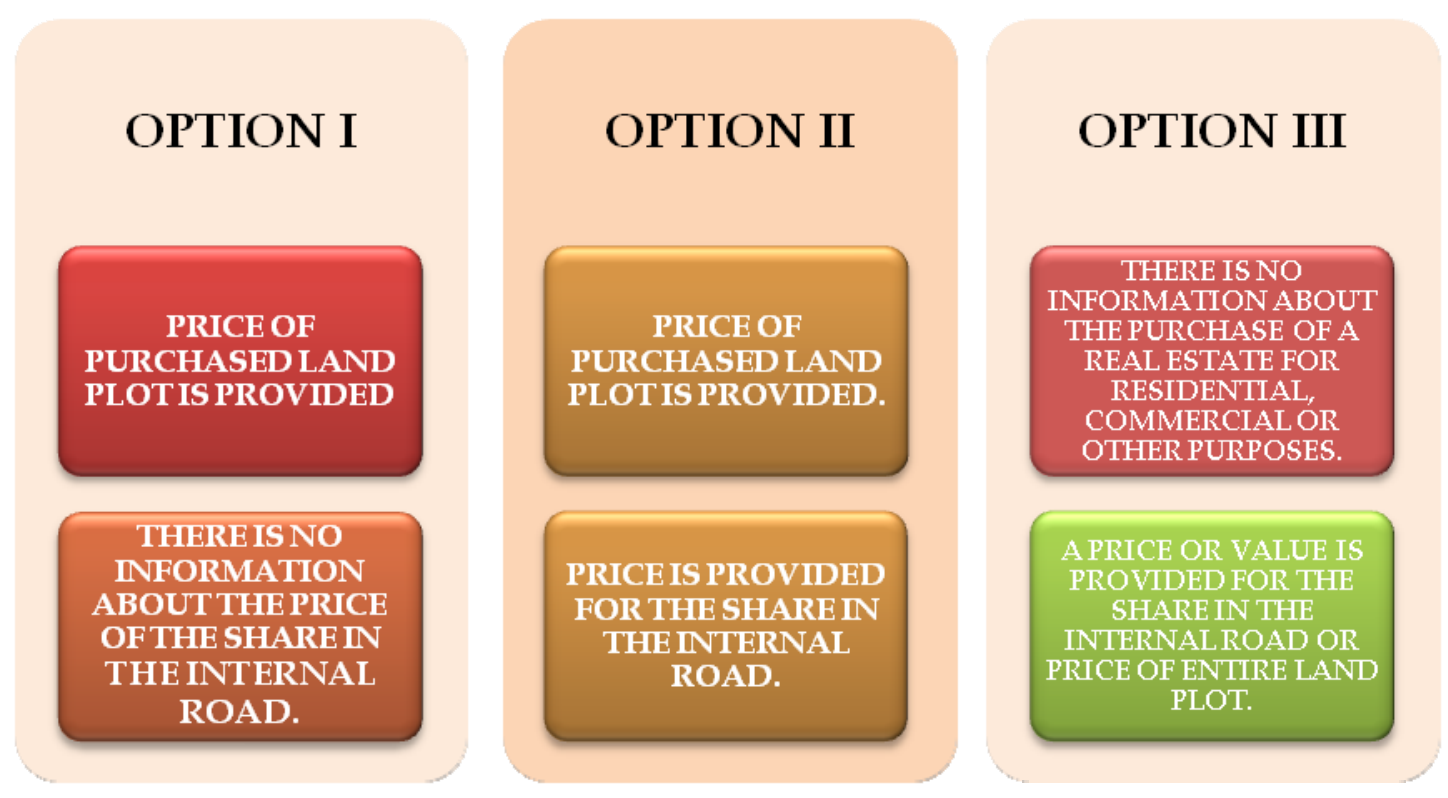

Fig. 6. Options of purchasing a share in an internal road in the area of analysis. Source: own study.

In the commune of Stawiguda, the majority of cases involving an internal road were observed in Tomaszkowo. Table 4 presents information about the total number of transactions with the acquisition of shares in an internal road, as well as a division into situations where the road has a more and less complex structure. Table 4 also includes information regarding the number of cases where the price of the share was provided.

Table 4

Analysis of acquisitions of real estate with a share in an internal road (2007-2011) - Tomaszkowo

\begin{tabular}{|c|c|c|c|c|}
\hline \multirow[t]{2}{*}{ Specification } & \multicolumn{2}{|c|}{$\begin{array}{c}\text { Acquisition of a share in an internal } \\
\text { road }\end{array}$} & \multirow[t]{2}{*}{ Total } & \multirow[t]{2}{*}{$\begin{array}{l}\text { Indication of } \\
\text { price }\end{array}$} \\
\hline & $\begin{array}{c}\text { Internal } \\
\text { road } \\
\text { consisting of } \\
\text { one plot }\end{array}$ & $\begin{array}{c}\text { Internal road } \\
\text { consisting of a few } \\
\text { plots }\end{array}$ & & \\
\hline $\begin{array}{l}\text { Number of cases - acquisition } \\
\text { of a share in an internal road }\end{array}$ & 30 & 28 & 58 & 17 \\
\hline
\end{tabular}

Source: own study based on register of real estate prices and values for Stawiguda.

According to data from the register of real estate prices and values, there were 138 transactions regarding the purchase of real estate in Tomaszkowo in the period between 2007 and 2011. Around $40 \%$ of them included the acquisition of shares in an internal road, among which the road is located within a single plot in $50 \%$ of them, and is comprised of a few plots (maximum of 6 ) in the others (Table 4). 
Only $30 \%$ of the transactions included information about the acquisition of a share in an internal road. Total prices of these shares are within the range of 500 to 8000 PLN. This is an insignificant part of the price of the entire real estate, where most of the unit prices are in the range of 40 to 200 $\mathrm{PLN} / \mathrm{m}^{2}$. If we transform prices of shares to unit prices, they do not amount to more than a few zlotys per square meter.

In Tomaszkowo, the acquisition of internal roads within the area of a housing estate is common. Fig. 7 presents a section of a settlement where we can observe this situation. As shown in the diagram, more than 20 plots have been purchased with a share in the highlighted internal roads in the housing estate in Tomaszkowo.

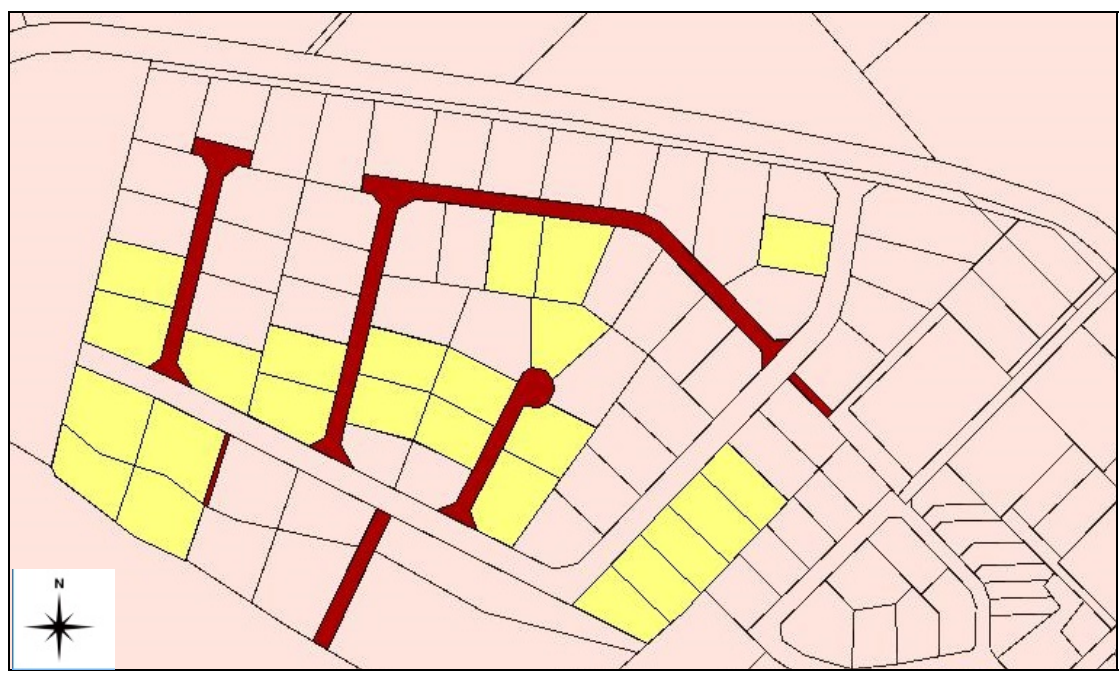

LEGEND :
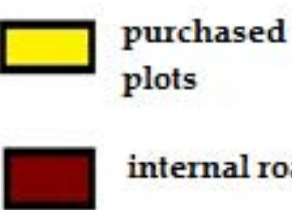

internal roads

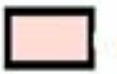

other plots

Fig. 7. Real estate in Tomaszkowo acquired along with a share in internal roads during 2007-2011.

Source: own study.

A selection of the commune of Dywity was also subjected to detailed analysis of internal road acquisitions. A relatively high contribution of transactions with acquisitions of shares in internal roads was noted in Ługwałd. Table 5 presents the data for this precinct, analogically to Table 4.

According to data from the register of real estate prices and values, 77 transactions were noted in the precinct of Ługwałd - twice fewer than revealed by the data for Tomaszkowo. Still, $45 \%$ of the descriptions of transactions included information about acquiring a share in an internal road. Unlike Tomaszkowo, $30 \%$ of the cases in Ługwałd concerned internal roads within a single plot, with the remaining $70 \%$ involving shares in internal roads consisting of a few plots (Tables 4 and 5). The internal road with the most complex structure consists of 3 plots.

Table 5

Analysis of acquisitions of real estate with a share in an internal road (2007-2011) - Ługwałd

\begin{tabular}{|c|c|c|c|c|}
\hline \multirow[t]{2}{*}{ Specification } & \multicolumn{2}{|c|}{$\begin{array}{c}\text { Acquisition of a share in an internal } \\
\text { road }\end{array}$} & \multirow[t]{2}{*}{ Total } & \multirow[t]{2}{*}{$\begin{array}{l}\text { Indication of } \\
\text { a price }\end{array}$} \\
\hline & $\begin{array}{c}\text { Internal } \\
\text { road } \\
\text { consisting of } \\
\text { one plot }\end{array}$ & $\begin{array}{c}\text { Internal road } \\
\text { consisting of a few } \\
\text { plots }\end{array}$ & & \\
\hline $\begin{array}{l}\text { Number of cases - acquisition } \\
\text { of a share in an internal road }\end{array}$ & 10 & 25 & 35 & 10 \\
\hline
\end{tabular}

Source: own study based on register of real estate prices and values for Dywity.

Just as in Tomaszkowo, nearly $30 \%$ of cases included information about the price of the share in the internal road. These total prices fell within the range of 50-5000 PLN. Again, this seems to be an insignificant part of the total price, where most of the unit prices of real estate ranged from 20 to 140 $\mathrm{PLN} / \mathrm{m}^{2}$. If we transform prices of shares into unit prices, they will not amount to more than a few zlotys per $\mathrm{m}^{2}$. 
Similarly to Tomaszkowo, participation in internal roads was demonstrated by a selection of real estate in the western part of Ługwałd (Fig. 8). In the period between 2007 and 2011, 17 plots were sold in this part of Ługwałd, with a share in an internal road consisting of 3 plots.
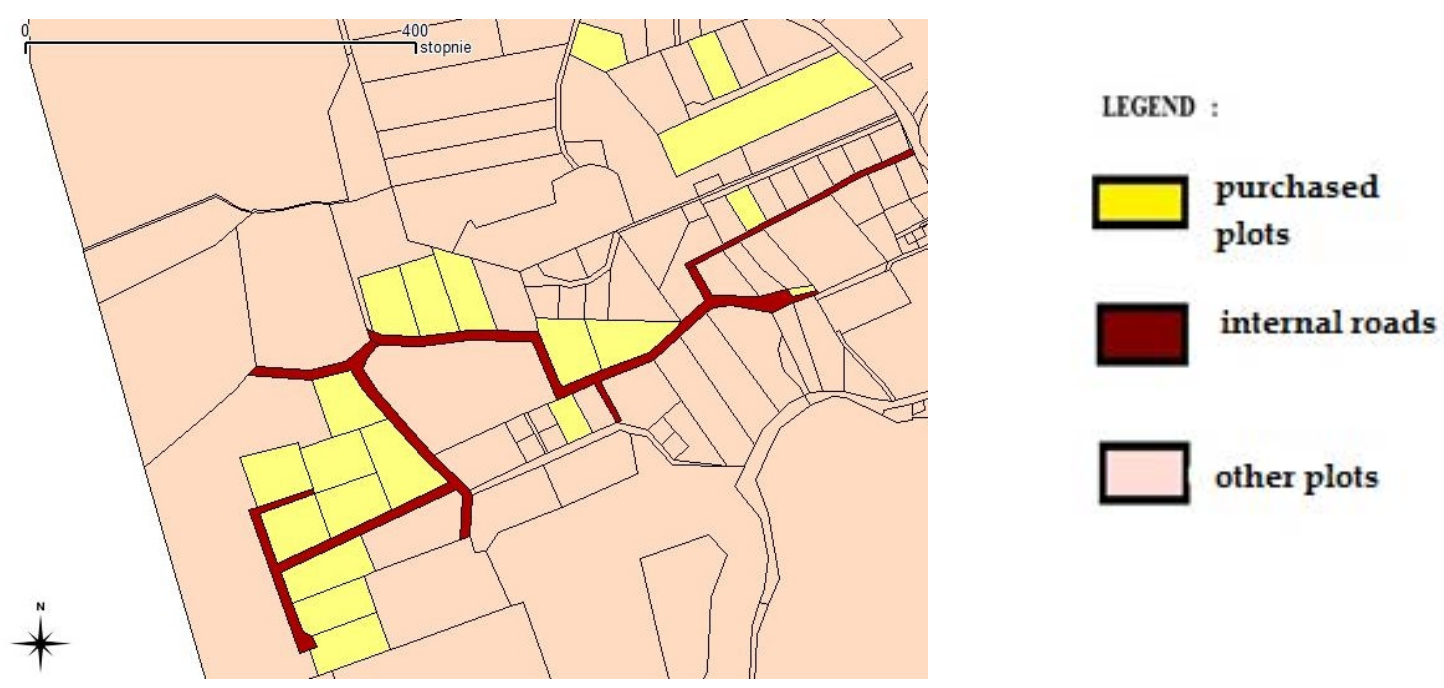

Fig. 8. Real estate in Ługwałd acquired along with a share in internal roads during 2007-2011. Source: own study.

The progressive acquisitions of plots with shares in internal roads, both in Tomaszkowo and Ługwałd, lead to the creation of settlements of a complex structure, with internal roads consisting of several fragments. It will be challenging for their users and co-owners to keep the transportation routes in proper technical condition. However, aiming to provide an access road to real estate in order to facilitate development (mainly residential) is so powerful, that such situations seem to be common throughout the research area.

To summarize the research concerning the access to a public road as a factor influencing the local real estate market, a comparison was made between the real estate transaction prices of two selected precincts (Eugwałd and Tomaszkowo). A pair of similar real estates were selected for each precinct, corresponding with each other in terms of land use designation, as well as the area and shape of the plot. Moreover, they are situated close to each other (distance within $500 \mathrm{~m}$ ), and with purchase-sale transactions made in the same year of analysis. The significant difference between them is the type of access to a road, i.e. direct access to a public road or indirect, via an internal road. The main purpose of the conducted analysis is to show the differences among the unit prices of selected plots. The results have been presented in Table 6 .

Table 6

Analysis of acquisitions of real estate located by public roads and internal roads in the precincts of Ługwałd and Tomaszkowo

\begin{tabular}{|c|c|c|c|c|c|c|c|}
\hline No. & $\begin{array}{l}\text { Date of } \\
\text { sale }\end{array}$ & $\begin{array}{l}\text { Registration } \\
\text { number of } \\
\text { plot }\end{array}$ & Function & $\begin{array}{l}\text { Area } \\
\left(\mathrm{m}^{2}\right)\end{array}$ & $\begin{array}{l}\text { Type of } \\
\text { road }\end{array}$ & $\begin{array}{l}\text { Unit price } \\
\left(\mathrm{PLN} / \mathrm{m}^{2}\right)\end{array}$ & $\begin{array}{l}\text { Difference } \\
\text { in quota } \\
\left(\mathrm{PLN} / \mathrm{m}^{2}\right)\end{array}$ \\
\hline \multicolumn{8}{|c|}{ precinct Ługwałd } \\
\hline 1 & 2011.07.07 & $133 / 33$ & $\begin{array}{c}\text { residential } \\
\text { single family }\end{array}$ & 1234 & $\begin{array}{c}\text { internal } \\
\text { road }\end{array}$ & 52.67 & \multirow{2}{*}{26.58} \\
\hline 2 & 2011.07.25 & $133 / 40$ & $\begin{array}{c}\text { residential } \\
\text { single family }\end{array}$ & 1388 & $\begin{array}{l}\text { public } \\
\text { road }\end{array}$ & 79.25 & \\
\hline \multicolumn{8}{|c|}{ precinct Tomaszkowo } \\
\hline 1 & 2010.05.13 & 118/10 & $\begin{array}{c}\text { residential } \\
\text { single family }\end{array}$ & 2546 & $\begin{array}{c}\text { internal } \\
\text { road }\end{array}$ & 140.61 & \multirow{2}{*}{33.74} \\
\hline 2 & 2010.05 .14 & $119 / 15$ & $\begin{array}{c}\text { residential } \\
\text { single family }\end{array}$ & 2173 & $\begin{array}{c}\text { public } \\
\text { road }\end{array}$ & 174.35 & \\
\hline
\end{tabular}


Source: own study based on register of prices and real estate values for Dywity and Stawiguda.

Table 6 shows the comparison between of the unit transaction prices of similar real estates chosen within the precincts of Ługwałd and Tomaszkowo. The selected plots were sold in the same month. They are all allocated for residential development (single-family detached housing) and situated within a distance of approx. $250 \mathrm{~m}$ (Ługwałd) and $350 \mathrm{~m}$ (Tomaszkowo) to each other. Moreover, the difference between the area of selected plots is not more than approx. $15 \%$ of the area of the smaller plot. As the comparison presented in Table 6 demonstrates, in both cases, plots with direct access to public roads are characterized by higher prices than plots with access via an internal road. Comparing this amount to the unit prices noted in both precincts, especially within Ługwałd, the difference appears to be significant. A divergence of unit transaction prices among the selected pairs at the level of 26-34 PLN $/ \mathrm{m}^{2}$ confirms the influence that transport accessibility has on the transaction price of real estate.

\section{Summary and conclusions}

The analysis conducted in this article confirmed the relationship between the development of suburban real estate markets and the transportation accessibility of the real estate. The progressive suburbanization of areas neighboring Olsztyn is reflected in the trends observed in local real estate markets. Local concentrations of transactions close to major transportation routes may be observed in both of the analyzed communes. In areas that are not directly adjacent to the main public roads but located at a distance of $2-3 \mathrm{~km}$ from the main routes, an internal system of communication has been developed. This occurs because the need to provide access to public roads (also via internal communication) is one of the main conditions for the realization of all kinds of building projects on a given real estate.

Tendencies occurring in the selected area can lead to the negative effects of urban sprawl, including an excessive burden on the road network, or insufficient parameters of the technical infrastructure. Considering the above, we reach the conclusion that complete information of the real estate market is not only a source of useful information for investors, but also important for preparing the concepts of planning and local development strategies.

\section{References}

BARRAS R., 1994, Property and the Economic Cycle - Building Cycles Revisited, "Journal of Property Research", No. 11, pp. 183-197.

FORYŚ I., PUTEK - SZELĄG E., 2008, Przestanki inwestowania w nieruchomości rolne na przykładzie AWRSP i ANR w zachodniopomorskim. (Conditions of Investing in Rural Real Estate on the Example AWRSP and ANR in the West Pomeranian Province), Studia i Materiały Towarzystwa Naukowego Nieruchomości (Journal of the Polish Real Estate Scientific Society), vol. 16 No. 4, Olsztyn.

Galster G., HANSON R., RatclifF M.R., Wolman H., Coleman S., FreiHAGe, 2001, Wrestling Sprawl to the Ground; Defining and Measuring an Elusive Concept, Housing Policy Debate, 12, 4, pp. 681-717.

GeURS K., VAN WEE B., 2006, Ex-post Evaluation of Thirty Years of Compact Urban Development in the Netherlands, in: Urban Studies, University of Glasgow, Vol. 43, No. 1, pp. 139-160.

GRANELLE J. J., 1998, Economie immobiliere. Analyses et applications, Economica, Paryż.

Gross M., ŹRÓBEK R., 2015, Good Governance in Some Public Real Estate Management Systems, Land Use Policy, 49 (2015), pp. 352-364 (online: http://dx.doi.org/10.1016/j.landusepol.2015.08.017 02648377).

HOPFER A., 2006, Gospodarowanie nieruchomościami na obrzeżach dużego miasta (Management of Real Estate on the Outskirts of the City.), WSGN (School of Real Estate Management), Warsaw.

KRAJEWSKA M., 2010, Analiza zmian wartości gruntów w strefach podmiejskich dużych miast. (Analysis of Changes in the Value of Land in Suburban Areas of Large Cities.), Studia i Materiały Towarzystwa Naukowego Nieruchomości (Journal of the Polish Real Estate Scientific Society), Vol. 18, No. 3 pp. 51-60, Olsztyn.

Kronenberg J., Bergier T. (red.), 2010, Wyzwania zrównoważonego rozwoju w Polsce. (Challenges of Sustainable Development in Poland.), Fundacja Sendzimira (Sendzimir Foundation), Kraków.

KUCHARSKA - STASIAK E., 2004, Nieruchomość a rynek. (Real Estate and the Market), Wyd. Naukowe PWN (Polish Scientific Publishers PWN), Warsaw. 
LisOWSKI A., GROCHOWSKI M., 2008, Procesy suburbanizacji, uwarunkowania, formy i konsekwencje. (Processes of Suburbanization, Conditions, Forms and Consequences.), Opracowanie przygotowane na zlecenie Ministerstwa Rozwoju Regionalnego (Research paper prepared to the order of the Ministry of Regional Development), Warsaw.

LORENS P., 2005, Suburbanizacja w procesie rozwoju miasta postsocjalistycznego (Suburbanization in the Development Process of a Post-Socialist City) in: LoRENS P. (ed.) Problem suburbanizacji (Suburbanization Problem), Biblioteka Urbanisty 7, Urbanista, Warsaw, pp. 33-44.

MiLEWSKI R., KWIATKOWSKI E., 2004, Podstawy ekonomii. (Principles of Economics), Wyd. Naukowe PWN (Polish Scientific Publishers PWN), Warsaw.

PeISER R. B., FrAj A. B., 2007, Professional Real Estate Development. The Uli Guide to the Business. Second edition, ULI, Washington.

Rottke N., Wernecke M., 2002, Real Estate Cycles in Germany - Causes, Empirical Analysis and Recommendations for the Management Decision Process, 8th Conference of the Pacific Rim Real Estate Society, 21-23 January 2002, Christchurch, New Zealand.

SAmuelson P., Nordhaus W., 1995, Ekonomia 1. (Economics 1), Wyd. PWN ( Polish Scientific Publishers PWN) Warsaw.

SMITH S., MunRo M., CHRISTIE H., 2006, Performing (Housing) Markets w: Urban Studies, University of Glasgow, Vol. 43 No. 1, pp. 81 - 98.

TROJANEK M., 2009, Uwarunkowania rozwoju rynku nieruchomości w Polsce. (Conditions for development of real estate market in Poland.) [in:] Uwarunkowania i rozwój rynku nieruchomości niezabudowanych na obszarach atrakcyjnych turystycznie w powiecie pulawskim. (Conditions and Development of the Market of Not Built-up Real Estate in Areas Attractive for Tourism in the Pulawy District) ed. KACPRZAK E., Bogucki Wydawnictwo Naukowe (Bogucki Scientific Publishing), Poznań, pp. 9-16.

WOLNY A., ŹRÓBEK R., 2008, Wptyw decyzji administracyjnych zatwierdzajacych projekt podziału nieruchomości na rozwój obszarów podmiejskich. (The Impact of Administrative Decisions Approving the Project of Dividing Real Estate for the Development of Suburban Areas.), Acta Sci. Pol. Administratio Locorum 7 (2), pp. 57-68 Olsztyn.

Wolny A., ŹRÓBEK-RÓŻAŃSKA A., ŹRÓBEK R., PiOTROWSKi M., FreY J., 2014, Development of Areas and Public Purpose Investments in the Suburban Territory, Real Estate Management and Valuation, Vol. 22, No. 2, pp. 86-97. ISSN (Online) 2300-5289, DOI: 10.2478/remav-2014-0020, July 2014.

www.stat.gov.pl, accessed 15.02.2015 r.

www.bip.warmia.mazury.pl, accessed 15.02.2015 r.

www.bip.stawiguda.pl, accessed 15.02.2015 r.

www.stawiguda.pl, accessed 31.12.2014 r.

www.gminadywity.pl, accessed 31.12.2014 r. 